Volodymyr Humeniuk,

Doctor of Science in Economics, Professor, Ivano-Frankivsk National Technical University of Oil and Gas, 15 Karpatska str., Ivano-Frankivsk, 76019, Ukraine,

ORCID: 0000-0002-8493-4470,

ResearcherID:N-9466-2017

Liudmyla Semyrga, Sales Manager,

«Join UP! to travel» agency, 10 Pereiaslavska str., Kolomyia, 78200, Ukraine

ORCID: 0000-0001-9558-8705

Halyna Umantsiv,

$\mathrm{PhD}$, Associate Professor, Kyiv National University of Trade and Economics, 19 Kyoto str., Kyiv, 02156, Ukraine

ORCID: 0000-0002-5410-1363

\title{
ECONOMIC BEHAVIOUR OF SINGLE CONSUMERS IN THE TOURISM SERVICES MARKET
}

The article discusses multidisciplinary aspects for the formation of Economic Behaviour of Singles' Consumers in the Tourism Services Market, which depend on the social, economic and cultural factors. The conceptual approaches to the essential identification of single tourism have been revealed. The criteria have been developed and the sociometric research of behaviour of singles in the tourist services market has been conducted. The materials of the conducted research can be used for development of methodological base of single tourism marketing researches, improvement of the system of statistical observations and state regulation of tourism.

Keywords: single tourism, economic behaviour, consumers, services market.

Relevance of the research topic. The world tendencies of development of tourism represent positive dynamics in demand for single travel, at the same time the share of the single tourism market is increasing in the highly developed countries of the EU and the world. However, the system of statistical observations in some developing countries still does not meet the requirements of users of tourist information. Single tourism statistics has not been kept in Ukraine since the time of its independence, whereas in the EU countries the single tourism phenomenon has been actively researched during the last decade. Taking into account the actuality of the 
problem and its insufficient scientific disclosure, the purpose of our research is to develop conceptual approaches aimed at revealing the essence of economic behaviour of single consumers in the tourist services market, assessing the current state, detection of tendencies of single tourism development.

Formulation of the problem. In economics, fundamental researches of interaction of supply and demand in the tourist services market, formation of the tourist environment, evaluation of economic behaviour of subjects of tourism business and consumers of services have been conducted. However, the existing approaches to organization of business processes in tourism firms, marketing activities and government regulation of tourism need to be reviewed and improved, taking into account the concept of behavioural economy, which reveals at the most the potential for ensuring the realization of market intentions of consumers who are essentially the creators of the tourist services market. The qualitative analysis and forecasting of market dynamics, changes in trends and tendencies require a thorough study of economic behaviour of consumers in the tourist services market.

Analysis of recent researches and publications. The scientific basis of the research of economic behaviour of consumers in the tourist services market are formed with scientific developments of well-known scientists, scientific practitioners, and analysts.

The fundamental developments of R. Taller (2018) in the field of behavioural economics, which studies influence of social, cognitive and emotional factors on economic decision-making by individuals and which analyses the effects of this influence on market processes, have caused new discussions in economics. The methodological aspects of the research of Economic Behaviour of Singles' Consumers in the Tourism Services Market, conceptual approaches to its evaluation in the conditions of structural and institutional transformation of the market were reflected in the works of Zakharchenko P., Kostenko A., Kungurtseva-Mashchenko T. \& Gorbachova I. (2019), Boyko M., Bosovska M. \&Vedmid N.(2019), Melnychenko S., Mazaraki N. \& Tkachuk, T. (2019), Dąbrowska, A. \&Janoś-Kresło M. (2018), Hladkyi O. \& Mirzodaieva T. (2018), Koval V. \& Mykhno Y., Antonova L., Plekhanov D. \& Bondar V. (2019),Humeniuk V. \&Shtan M. (2019) and other researchers

Presenting the main material. In the general economic context, consumer behaviour in the tourist services market can be considered on general principles as a behaviour of consumers in any sphere which depends on various influential factors, although in fact it is a complex of actions connected with decision making, a choice and a purchase of tourist services and its consumption, as well as taking into account the branch specifics of tourism and peculiarities of consumer behaviour during their travel.

From an economic point of view, a single person is a sole household. The system of basic determinants of households, in terms of separate parameters of their 
identification as market entities, takes into account that a single person is an institutionally independent unit that resides independently and manages financial resources.

The recent statistical researches of single-family households in the EU show that in 2018 about $1 / 3$ of all households were occupied by single-family households of adults without children (Fig. 1).

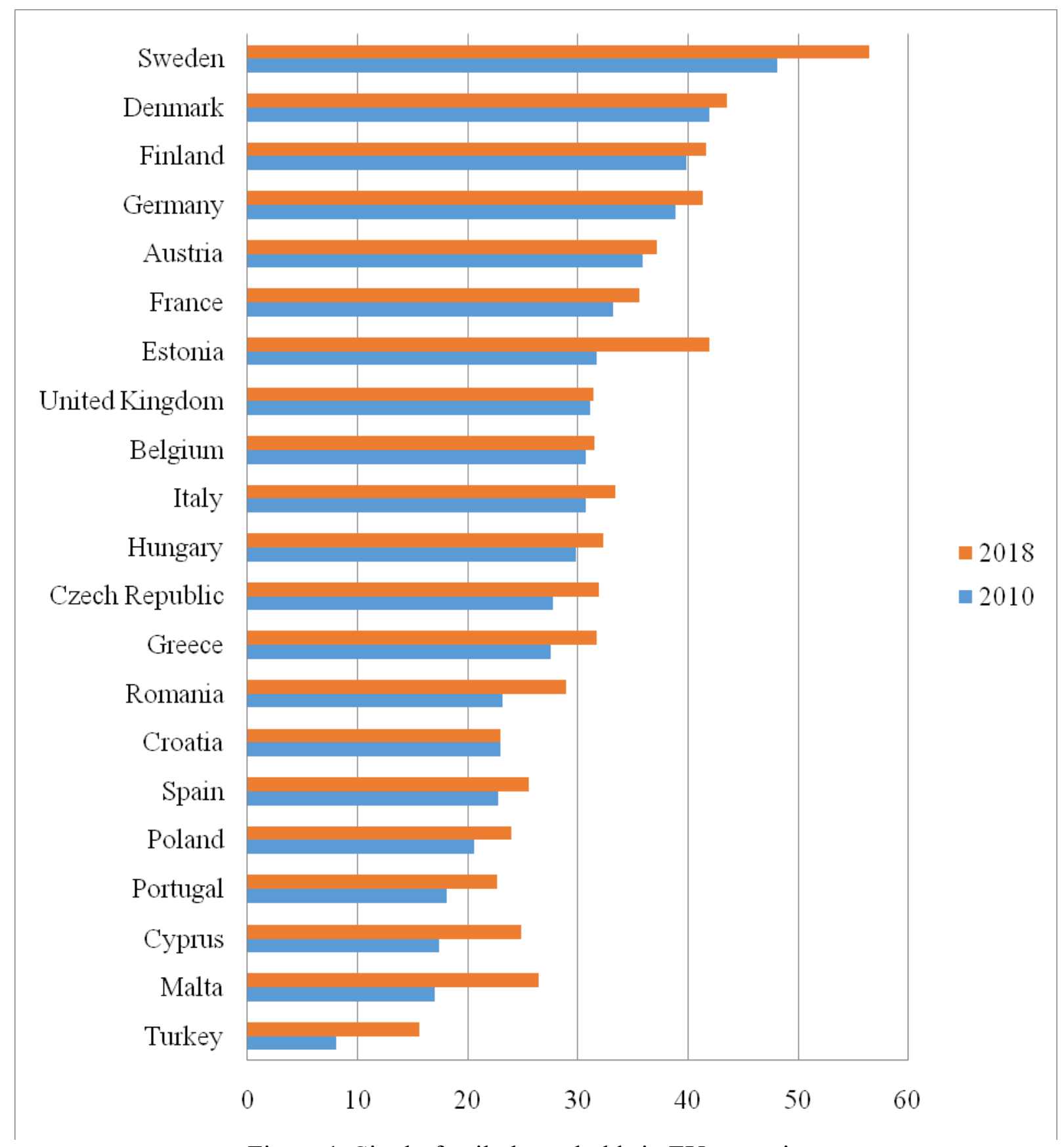

Figure 1. Single-family households in EU countries

Source: Data from the EU statistical consortium (EU statistical consortium EUROSTAT (2018), Figures daising proportion of single person house holds in the EU. Available at: https://ec.europa.eu/eurostat/ web/products-eurostat-news/-/DDN-20180706-1?inheritRedirect=true) 
The data in Figure 1 indicate that in comparison with 2010, the share of singlefamily households in the EU in the aggregate represented 31 per cent, and in 2018 this figure increased to 34 per cent.

Taking into account the factors of affinity and difference of economic, social, cultural development and geographical neighbourliness, let us consider the peculiarities of determination of single tourism in the example of Poland and Ukraine.

Polish single tourists are mostly 25-45 year olds, most of whom organize their own trips and are in travel for a long period of time. Almost every second Polish single person is an office employee or is engaged in mental work. More than 1/5 of Polish single persons inform that they use gastronomic, recreational, sports and cultural services every year more often, and also organize tourist trips on their own to a greater extent than before. That is why they are less likely to use travel services organized by travel agencies. Only one among four people interviewed had a special offer for single persons, though anyway these individuals still think it insufficiently suited to them. Every third respondent thinks that such offers have become bigger over the last few years, but they have the following problems when choosing a tourist product: the lack of special offers for single persons, unlike discounts for families, small amount or the complete lack of hotel rooms for one person and too high additional payments for such accommodation (Dąbrowska A., Janoś-Kresło M., 2018, pp. 20-21).

Unlike Polish single persons, Ukrainians stated that they have no insured financial assets, moreover 27 per cent of respondents use financial assistance from abroad. It is worth noting that in the sample of 100 people in Ukraine aged 25-44, 37 people have completed higher education, while in Poland 67 people per 100 respondents (Statistical Yearbook of Ukraine, 2018).

Assessing the scale of single tourism and current trends of its development, we can say that a new segment of consumers has emerged in the tourist services market which includes single persons-travellers who deny the existing social values, they can think and act differently, act as original «rebel buyers» and thus to disturb market processes, to change the market conjuncture.

Market terminology in international tourism business does not contain the notions of «young ladies» and «gentlemen», but the definition of «Singles» has become practically consolidated. To be a single person is becoming more popular and more and more people are consciously choosing this lifestyle. Just with their participation the tourist market is reviving, demanding absolutely new offer addressed to single persons. At the same time, when buying a tour with a travel agency, single travellers have to choose whether to pay for a single room for 30-80 per cent more, or to live with a stranger in a double room. That is why single persons often organize vacations independently with the help of online agents. In this connection, in order not to lose such a target group of consumers as single persons, tour operators should 
modify their offer of tourist services in the market taking into account the needs of single persons.

The system of organized statistical observations in Ukraine does not currently foresee formation of a database concerning economic behaviour of single tourists, their motives and needs. Just because of the lack of proper information regarding economic behaviour of single tourists in the framework of scientific and research work on the «International Hotel and Tourism Business» Educational Program at Ivano-Frankivsk National Technical University of Oil and Gas in cooperation with stakeholders, and travel companies «Join UP! to travel «(Kolomyia),» Rest-Travel «(Kiev) in particular, a sociological research in the regime of online questioning of consumers of tourist services from different regions of Ukraine have been conducted (Humeniuk V. \&Semyrga L., 2020). 240 people who are completely different in age, employment, social status and income participated in the survey. The survey was conducted during four months: from the 1st of November 2019 to the 29th of February 2020.The age structure of the respondents is quite diverse (Fig. 2).



Figure 2. Age of respondents, \%

Source: To build this diagram, the authors have used data received exclusively from the results of their own sociological research of the economic behaviour of single tourists.

The largest share of the market segment of single tourism, as it is shown in Figure 2, is comprised by consumers aged 21-30 (35 per cent) and the smallest group is comprised by people at the age of 60 and over, but it is important to know that such persons can also travel actively and usually independently. Due to low purchasing power of people of retirement age in Ukraine, the tourist market has very little to offer them. 
It should also be noted that the largest proportion of respondents who indicated that they are married or have a couple, or date, however, can travel alone (64.1 per cent). Only 31.3 per cent declared themselves as «single persons» without a pair and 4.6 per cent divorced. Therefore, it is clearly seen that the Ukrainian single tourist is not only absolutely a single person, as it may seem to suppliers of a tourist product on the market, but they are also family persons. These results clear up their large share of consumers of travel services, because when traveling on business or having a rest on weekends, they form a stream of single tourism.

This is confirmed by the answers regarding motivation of such trips. 49.6 per cent chose «the desire to rest from others» as the decisive factor of traveling alone, 38.7 per cent mostly travel independently due to business trips and work trips and only 20.6 per cent mostly travel alone due to the absence of a partner.

One of the important questions that were given to individuals concerned the types of tourism that interested them most. Respondents in this case had the opportunity to indicate several answers, so the results highlighted the proposal of which kind of tourism should be reviewed and tried to adapt to the expectations and needs of single tourists (Fig. 3).

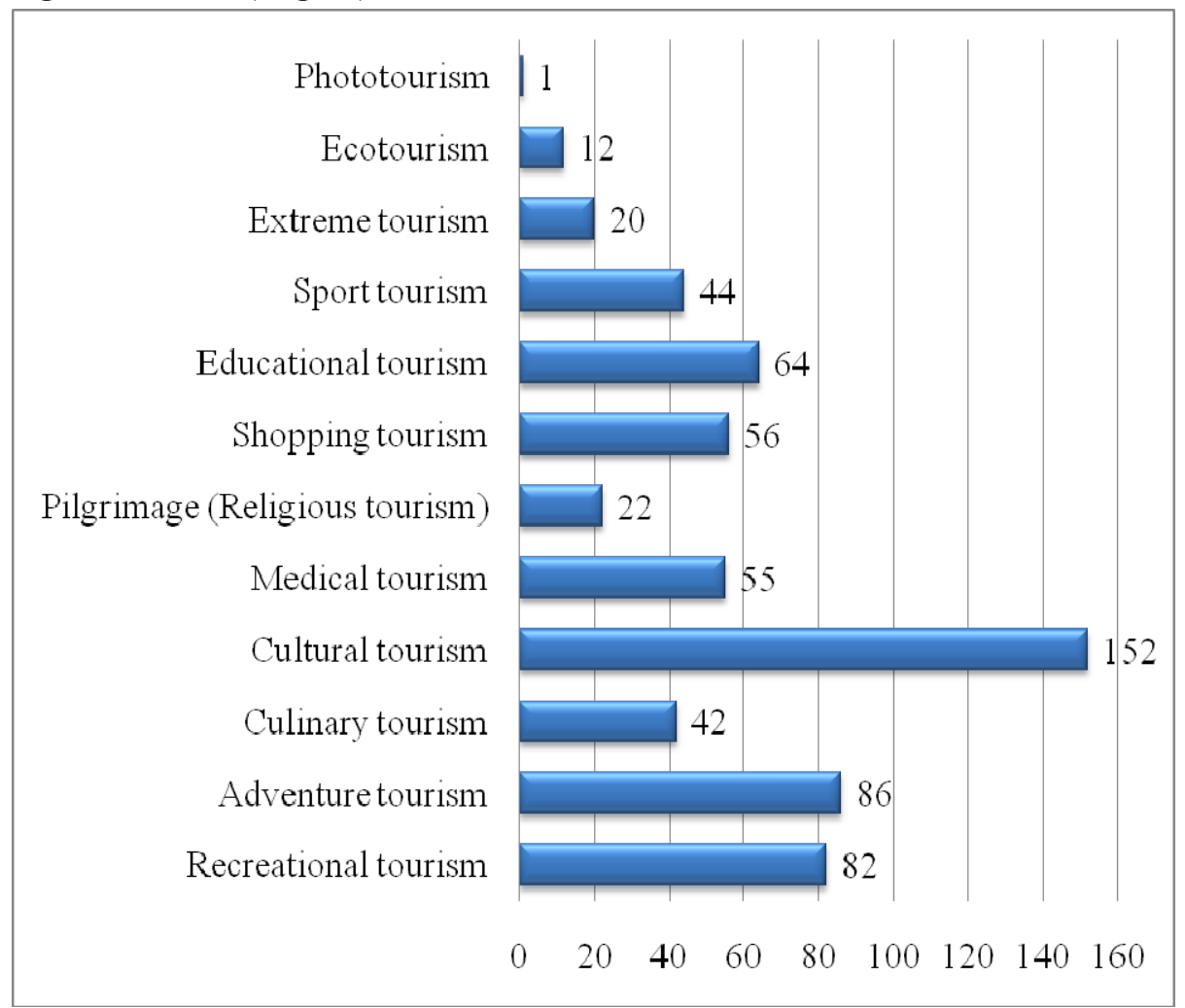

Figure 3. Priority types of tourism, persons

Source: To build this diagram, the authors have used data received exclusively from the results of their own sociological research of the economic behaviour of single tourists.

As Figure 3 illustrates, the most interesting for single persons is an excursion and informative tourism, which was marked by 152 people ( 63.1 per cent). Also very interesting for single tourists is adventure and entertaining, and recreational and 
relaxation tourism, which comprised 35.7 per cent and 34 per cent respectively. Educational tourism also has a significant share in this structure (26.6 per cent).

However, in the international hotel and tourism business, it is also important to operate with information concerning the most popular destinations among single tourists. The results of the observations on the priority tourism directions are given in Figure 4 .

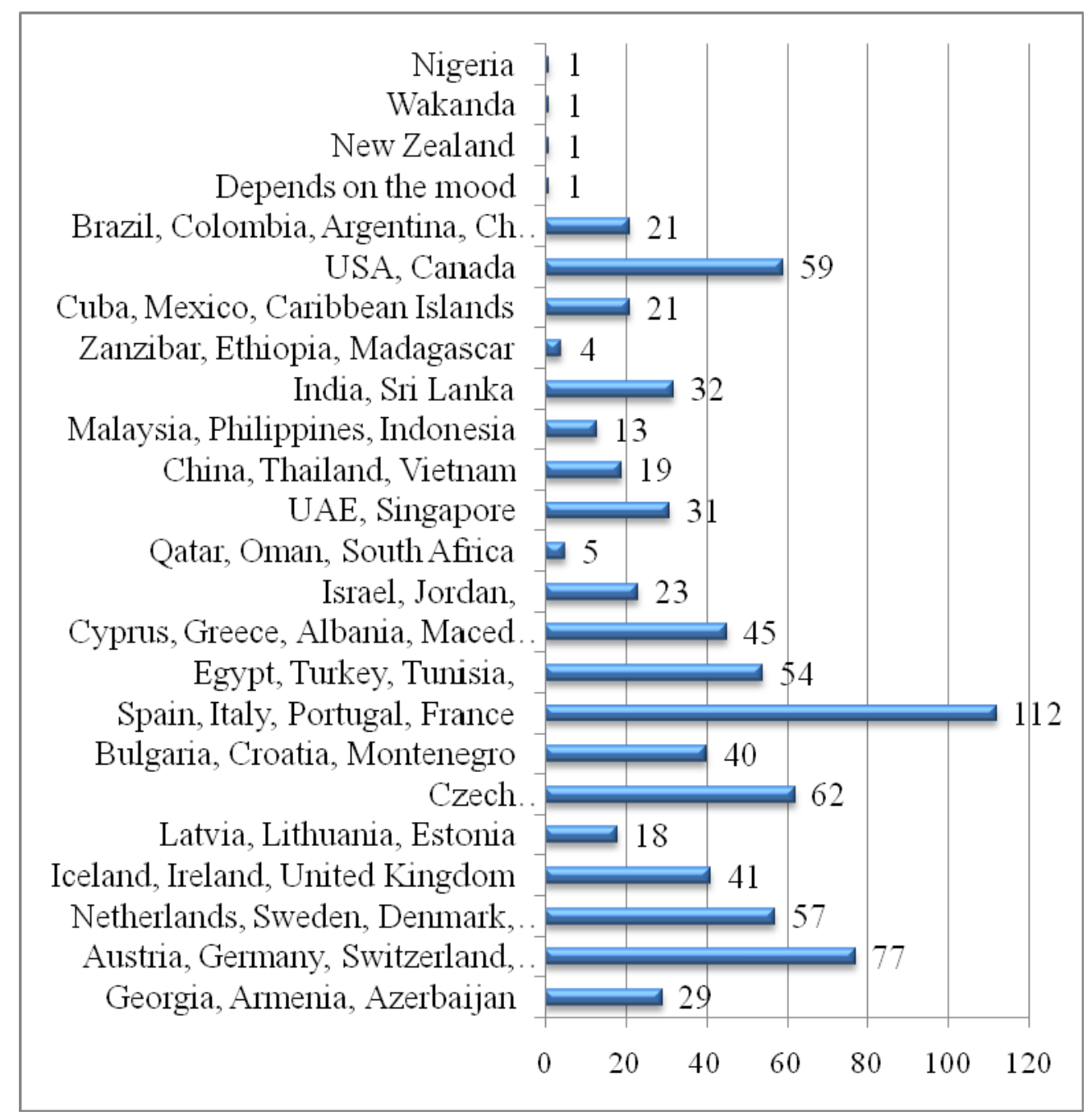

Figure 4. Popular destinations for singles, persons

Source: To build this diagram, the authors have used data received exclusively from the results of their own sociological research of the economic behaviour of single tourists.

The most attractive for Ukrainian single tourists, as illustrated in Fig. 4, are destinations in the Mediterranean basin, 112 people have marked it as desirable destination in their travel geography (54.9 per cent). Although the German-speaking countries and northern European countries have almost twice as low index, it still does not diminish their role in the structure of the desired tourism offer for single tourists.

According to the results of the conducted research it has also been clarified that 54.6 per cent of respondents are employees and 14.6 per cent are studying and working; 71,3 per cent have higher education, 36,9 per cent of them have a scientific degree; the 
vast majority of respondents travels several times a year for 3-6 or 7-9 days; 45.6per cent choose summer for their travel most often, but almost 40 per cent indicated that their choice does not dependent on the time of a year; 26,4 per cent get about 7-10 thousand UAH of income per month, and 29.3 per cent - within 10-20 thousand UAH.

Considering the level of respondents' income, the answers in the research were split almost proportionally: 33 per cent are ready to spend from 6 to 10 per cent of their annual income on their vacation, 29.5 per cent are ready to spend from 10 per cent to 15 per cent of their annual income and 26.67 per cent will save more than 15 per cent per year on their travel.

In financial terms, traveling for a single person causes more formal costs than for a person who travels in pairs. During a holiday, a single person will not spend as much money as a couple or a family spends, but the key moment is the cost of living for a single person in a hotel or apartments. It ranges on average from 60 per cent to 80 per cent of the cost of accommodation in a room for two persons. That is why during the survey only 20 per cent of respondents are ready to pay extra money for their overnight stay in a room alone. 37 per cent indicated «Most likely, yes», but doubt among such respondents is present, so having the opportunity not to pay extra money, they would definitely use such a possibility (Table 1).

Table 1

\section{Division of Respondents' answers to questions on travel preferences}

\begin{tabular}{|c|c|c|c|c|c|}
\hline \multirow[b]{2}{*}{ Question } & \multicolumn{5}{|c|}{ Answer } \\
\hline & 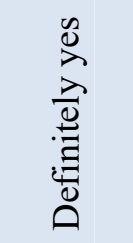 & 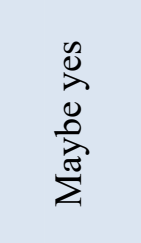 & 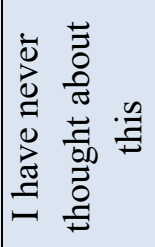 & 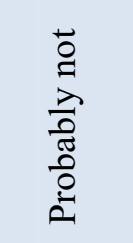 & 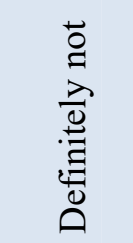 \\
\hline $\begin{array}{l}\text { Usually the cost of living for one person in a room } \\
\text { alone is higher than for two people. Are you ready } \\
\text { to pay for the comfort of a night out alone? }\end{array}$ & $20 \%$ & $37,08 \%$ & $20,83 \%$ & $15 \%$ & $7,08 \%$ \\
\hline $\begin{array}{l}\text { Do you use the services of travel agencies or tour } \\
\text { operators? }\end{array}$ & $54,58 \%$ & - & - & - & $45,42 \%$ \\
\hline $\begin{array}{l}\text { Do you organize your vacation on your own } \\
\text { without the help of intermediaries and tour } \\
\text { operators? }\end{array}$ & $77,5 \%$ & - & - & - & $22,5 \%$ \\
\hline Are tour operator offers tailored to your needs? & $7,92 \%$ & $36,67 \%$ & $33,33 \%$ & $14,58 \%$ & $7,5 \%$ \\
\hline $\begin{array}{l}\text { Are you interested in organized package tours of } \\
\text { mass tourism destinations (Turkey, Egypt, Tunisia, } \\
\text { etc.)? }\end{array}$ & $18,33 \%$ & $35,42 \%$ & $14,58 \%$ & $18,75 \%$ & $12,92 \%$ \\
\hline
\end{tabular}

Source: To build this table, the authors have used data received exclusively from the results of their own sociological research of the economic behaviour of single tourists. 
The results of the research which are presented in Table 1 showed that 77.5 per cent of respondents organize their trips independently, however, just a little bit more than a half of single tourists used the offers of travel agencies and tour operators (54.58 per cent) and the rest ( 45.42 per cent) did not address travel agents at all. At the same time, this indicator shows that although 32 per cent used the services of travel agents some time, they still prefer to plan and organize their vacations independently.

The reason for this phenomenon may be the lack of adaptation of an offer on the market to the needs of such a person. For this reason, only slightly more than 7 per cent gave a sure answer that offers of travel agencies and operators are sufficiently adapted to their needs. The same share was comprised by the group of respondents, who are convinced that they do not need services of travel agents and the product offered on the tourist services market is no longer actual and does not suit them.

As for the possibility to choose between a more expensive individual tour which is formed according to all wishes and a «hot offer», which is not quite suitable for a tourist but is cheap in cost, single tourists preferred an individual tour (140 responses -58.33 per cent), which testifies about their desire to get a tourism product adapted to their needs.

Conclusions. Organized statistical surveys of behaviour of different categories of consumers in the tourist services market are being conducted in the EU countries, which allows to identify a separate marketing segment of single tourists during the last decade, but in Ukraine single tourists are still remain a part of the overall statistics and it is quite possible that because of poor marketing performance in this segment, they will not get the proper travel service to the extent they need.

The results of the conducted research have practical importance for the tourism business, because economic behaviour of consumers determines the volume of demand and is an important condition for modifying the market supply for tourist services. Taking into account various aspects of this research, tour operators which create a product for single tourists need to adequately assess tourist demand and develop appropriate package tours for the future.

Hotel and tourism business when creating a proposal for single tourists should take into account the possibility of non-price competition, because true single tourists when choosing a particular vacation think it less important about what offer has a discount or promotion, they look for new experiences and impressions, but not stereotypical cheap travels. The results of the research confirmed that the tourist services market in Ukraine has considerable potential for development in terms of meeting the demands of singles. 


\section{REFERENCES}

1. Boyko, M., Bosovska, M., Vedmid, N. (2019). Global imperatives formation of tourist destination brand. Global Imperatives for Business and Law Development: II International Scientific and Practical Conference (Kyiv, October, 10-11, 2019,). Kyiv: KNUTE. pp. 428-438. Available at: http://doi.org/10.31617/k.knute.2019-1010.11 [in English].

2. Dąbrowska, A., Janoś-Kresło, M. (2018). Zachowania singli na rynku usług i e-usług. Implikacje dla marketingu. Handel Wewnętrzny. Instytut Badań Rynku, Konsumpcji i Koniunktur. Vol.2 (373), pp. 18-26. Available at: http://cejsh.icm.edu.pl/cejsh/element/bwmeta1.element.desklight-9724682f-4f74-4b528737-73a11c1a15a3 [in Polish].

3. EU statistical consortium EUROSTAT (2018), Figures daising proportion of single person households in the EU. Available at: https://ec.europa.eu /eurostat/web /products-eurostat-news/-/DDN-20180706-1?inheritRedirect=true [in English].

4. Hladkyi, O., Mirzodaieva, T. The development of recreation science as the main theoretical fundamental of tourism integrations. Dnipropetrovsk University BulletinSeries-geology Geography. Vol 26, No 1. pp. 33-40. Available at: https://doi.org/10.15421/111804

5. Humeniuk, V., Semyrga, L. (2020). Online survey for studying the economic behaviour of single tourists. Available at: https://docs.google.com /forms/d/1gKnP5kJhv7dA5EeiBiHfv3sD2YZgmQtk2GK3D7J_Tf4/edit?ts=5dc92748 [in Ukrainian].

6. Humeniuk, V. (2019), Financial security of enterprises in resort and recreation sphere, Financial and credit activity: problems of theory and practice Vol. 1, No 28 pp. 87-94. Available at: https://doi.org/10.18371/fcaptp.v1i28.164013 [in English].

7. Humeniuk, V. (2018), Financial nature of resort multiplier, Financial and credit activity: problems of theory and practice, no. 25, vol 2, Ukraine, pp. 417-423. Available at: https://doi.org/10.18371/fcaptp.v2i25.136501 [in English].

8. Humeniuk, V., Shtan, M. (2019). Concepts of Regulation of Resort and Recreational Services Pricing in the Conditions of Globalization. Global Imperatives for Business and Law Development : II International Scientific and Practical Conference (Kyiv, October, 10-11, 2019). Kyiv: KNUTE. P. 428-438. Available at: http://doi.org/10.31617/k.knute.2019-10-10.50 [in English].

9. Koval, V., Mykhno, Y., Antonova, L., Plekhanov, D., Bondar, V. (2019). Analysis of environmental factors' effect on the development of tourism. Journal of Geology, Geography and Geoecology, 28(3), 445-456. Available at: https://doi.org/10.15421/111941 [in English]. 
10. Melnychenko, S., Mazaraki, N., \& Tkachuk, T (2019). Leading trends in tourism: blockchain in franchising. Advances in Social Science, Education and Humanities Research, Proceedings of the 3rd International Conference on Social, Economic, and Academic Leadership (ICSEAL 2019). Vol. 318. pp. 388-395. Available at: https://doi.org/10.2991/icseal-19.2019.61 [in English].

11. Statistical Yearbook of Ukraine. Socio-demographic characteristics of Ukrainian households in 2018 (2018), State Statistics Service of Ukraine, Kyiv., 86 p. Available at: http://www.ukrstat.gov.ua/druk/publicat/kat_u/2018/zb/07/zb_sdhdu 2018pdf.pdf [in Ukrainian].

12. Thaler, R. (2018). Economía del comportamiento: pasado, presente y futuro. Revistade Economía Institucional. Vol.20, pp.9-43. Available at: http://dx.doi.org/10.18601/01245996.v20n38.02 [in English].

13. Umantsiv, I., Lebedeva L., Mitrofanova, A. (2019). Modern trends in governance of state ownership relations. Baltic Journal of Economic Studies. 2019. Volume 5. Number 5. p. 155-164 Available at: http://dx.doi.org/10.30525/22560742/2019-5-5-155-164 [in English].

14. Zakharchenko, P., Kostenko, A., Kungurtseva-Mashchenko, T., Gorbachova, I. (2019), Modeling expectations of resort-tourist market of Ukraine, The $8^{\text {th }}$ International Conference on Monitoring, Modeling \& Management of Emergent Economy (M3E2 2019), Vol65. Available at: https://doi.org/10.1051/shsconf/ 20196505001 [in English]. 